\title{
An Analysis of Students' Difficulties in Conducting the Scientific Research: A Case of Study of English Education Study Program and Economic Education Study Program of Universitas Negeri Gorontalo in Indonesia
}

\author{
Moon Hidayati Otoluwa ${ }^{1} \square$ Wulan Mayasari Tambengi ${ }^{2}$ and Hariansyah Igrissa Tambengi ${ }^{3}$ \\ ${ }^{1}$ Graduate Study Program of English Education, Universitas Negeri Gorontalo, Indonesia \\ ${ }^{2}$ Study Program of Economic Education, Universitas Negeri Gorontalo, Indonesia \\ ${ }^{3}$ Study Program of English Education, Universitas Negeri Gorontalo, Indonesia \\ $\square$ Corresponding Author: Moon Hidayati Otoluwa, E-mail: moonhidayatotoluwa@gmail.com
}

ARTICLE INFORMATION ABSTRACT

Received: 08 October 2021

Accepted: 07 November 2021

Published: 12 November 2021

DOI: $10.32996 /$ ijels.2021.3.11.2

\section{KEYWORDS}

Students' Difficulties, Scientific

Research, University Students
This current study explored the students' difficulties in conducting scientific research at the undergraduate level. This study was done in the English Education Study Program and Economic Education Study Program of Universitas Negeri Gorontalo. It utilized the descriptive qualitative design. Three undergraduate students at the English Education Study Program and three undergraduate students at the Economic Education Study Program were selected. Academic advising problems data were collected by using interviews. Data were descriptively analyzed, and this study revealed the students were reported to have experienced academic advising problems. The results demonstrated major factors that caused the students' difficulties in conducting scientific research were difficulty in determining the topic of the thesis, insufficient knowledge in writing the thesis, anxiety in interacting with the thesis advisors, limited access to interact with the lecturers, limited access to the availability of the books, the student's desire to build friendships and expansion with their advisors, and expectation of joy and excitement that comes with creative work.

\section{Introduction}

Thesis or scientific research is the most crucial or vital writing up for the students to get graduated from college. Writing a thesis is not as easy as writing an essay. Conducting a thesis has been proven very difficult and hard for the students. They may carry out an essay or mini research easily, but writing a research document in the form of a thesis is something that they can not do easily. Students face different kinds of difficulties in conducting their thesis writing. This happens because a thesis should be the combination of the right words in the right place and in the right order that is often confusing the students. Having to write a thesis, a researcher will naturally get confused on how to put things together in the thesis, starting from the background, theoretical framework, methodologies of research, and research findings and discussion. Lack of adequate vocabulary is one of the problems that will put the students into difficulties in conducting thesis writing too. A researcher also needs sufficient knowledge in the particular study that they carry out. Thus, the researcher needs to read a lot in order to write or conduct a thesis.

Based on the mini observation conducted by the English Education Study Program and Economic Education Study Program, it was revealed that there is only $0.1 \%$ of the students could graduate in three years and a half. Moreover, there are only $17 \%$ of the students who could graduate on time or four years exactly. This indicates that there is something that should be understood and figured out either by the faculty members or, the department members in order to raise up the percentage of the students who could graduate on time. In order to understand and figure out this phenomenon, research towards the students' difficulties in conducting research should be carried out. Thus, by considering those aspects, it is believed that this problem should be solved out; however, the first thing that should be done in order to find a solution for this problem is to understand the difficulties that the students encounter during the thesis writing or conduction.

Copyright: (C) 2021 the Author(s). This article is an open access article distributed under the terms and conditions of the Creative Commons Attribution (CC-BY) 4.0 license (https://creativecommons.org/licenses/by/4.0/). Published by Al-Kindi Centre for Research and Development, London, United Kingdom. 
Something that must bear in mind is that thesis conduction is one of the major academic activities. Thus, it is needed to find out and to analyze the difficulties that are encountered by the students during the thesis conduction or thesis writing, especially in the English Education Study Program and in the Economic Education Study Program, Universitas Negeri Gorontalo. Based on this assumption, there are several questions which are needed to be discussed and answered in order to acknowledge people especially those who put great interest in the educational side. Thus, the question below will be the core of this research: What difficulties do the English Education Study Program students and Economic Education Study Program encounter in the process of their thesis or Scientific research conduction?

The objectives of this research are to find out the students' difficulties in conducting thesis writing and to figure out the difficulties that become big barriers for the students to conduct their thesis research. The last, this paper purpose is to formalize this notion of the thesis conduction problems and to share it with other readers.

\section{Literature Review}

\subsection{General Difficulties in Conducting Thesis}

In conducting a thesis, the students may face many kinds of problems and obstacles. This can be a barrier for the students in finishing writing their thesis. According to Kutz and Hartnett (2001, p. 55), there are seven problems frequently associated with the thesis conduction, those are:

\subsection{Difficulty in determining the topic of the thesis}

When selecting a topic of thesis research, students are rarely provided with enough information about certain topics in certain study fields that allows them to make a sufficiently informed choice. Students require all sorts of information from their interests but feel no similar responsibility to make themselves known to their prospective students.

\subsection{Insufficient knowledge in writing thesis}

Students often lack knowledge on how they must structuralize and systematically write their thesis writing. Instead, they find themselves being pushed into relative intellectual isolation from other people and concentrating on a narrow specialty that few can share with them.

\subsection{Anxiety in interacting with the thesis advisors}

Students expect lively interactions, that is, sharing ideas and working with their thesis advisors. Yet, they often find very uncomfortable atmospheres and inadequate opportunities for working with their thesis advisors.

\subsection{Limited access to interact with the lecturers}

Graduate students may find themselves held to inquiries that do not reflect their own interests and intellectual predilections, but, rather, that of their lecturers. What is worse, they often labor in the thesis that drags out and is doubly difficult to finish because the subject they are delving into is not congruent with their own talents, motivations, and curiosity.

\subsection{Students have limited access to the availability of the books as the relevance of their study}

Instead, some students find difficulties in finding the right literature books to support the thesis or research that they conduct. This may lead the students to get stuck on conducting their thesis.

\subsection{Students want friendship and expansion with their advisors.}

Instead, the students feel anxiety in interacting with their thesis advisors and this makes them inflexible to communicate with their advisors especially in discussing the issues or problems that they face during the conduction of their thesis writing.

\subsection{Students expect the joy and excitement that comes with creative work.}

Instead, they find their lives are pushed by their family or friends. This makes their moods grim. As a matter of fact, the students may get depressed with all the force all around them thus, they cannot write and think their thesis clearly. This could lead the students into boredom in finishing their thesis.

Thus, it can be concluded that many enrolled students have reported dissatisfaction with the quality of their thesis conduction. Many students indicated that they thought about quitting before completing their thesis conduction. Haworth (2003, p. 78) explained that one-quarter of the students who entered the university in most universities in Auckland left between years one and three of graduate study, 10 percent left between years four and eleven, and 5 percent had degrees that were still pending at the time of her/his study. Some of the students do not get past the general comprehensive examinations, a stage that is potentially the single most stressful experience in thesis writing. 


\section{Methodology}

This research adopted the qualitative approach. The qualitative research shows how and why a phenomenon or reality communication occurs. Generally, qualitative research deals with words as the data analysis rather than numbers. Moreover, the method that is going to use in this research is the descriptive method. The descriptive method aims to make a systematic description, factual and accurate information on the facts, and the properties of the population of a particular area (Suryana, 2010). It further explains that descriptive research seeks to describe a phenomenon, events that occurred by now.

For this research, the inquirer or the researcher seeks to examine an issue related to the oppression of individuals/students in the domain of their points of view or perspectives to the difficulties that they encounter during the thesis writing or conduction. To study this, the approach is taken of collecting stories of the students who are composing their thesis writing oppression using a narrative approach. The students who are conducting their thesis will be interviewed at some length to determine how they have personally experienced oppression towards the difficulties they face while conducting their thesis.

\subsection{Source of Data}

Primary data was data obtained by researchers directly from the result of the observation and interview, while secondary data was data obtained by researchers from existing sources. In this research, three students of the English Education Study Program and three students of the Economic Education Department were the source of data. They were students who were composing their scientific research.

\subsection{Site and Participants}

The research sites were the English Education Study Program and the Economic Education Study Program at Universitas Negeri Gorontalo. The site was chosen considering the aspect of the participants of this research, accessibility, and flexibility in conducting this research.

The participants of the study consisted of three students from the English Education Study Program and three students from Economic Education Study Program. The students have spent more than four years in the university and are still working on their thesis. The technique of selecting the participants was the snowball rolling sampling method where the first participant has been selected based on the criteria that they were composing their research proposals. The next participant was chosen by the first participant and it was done continuously until three students were gathered. The three participants for each study program were chosen by considering the aspects of minimum participants and the flexibility of this research conduction. Suryana (2010) stated that the minimum participants of the qualitative research are three people who could be chosen based on purposive sampling or snowball rolling sampling.

\subsection{Technique of Data Collection}

The interview was used in collecting the data of this study. In this study, the semi-structured interview was used. The instruments which used in the interview section are audio recording, notebook, and questions list. This interview describes the result of the research on what are the students' difficulties and obstacles they face while conducting their thesis and the strategies used by the students in overcoming those obstacles or problems.

\subsection{Technique of Data Analyses}

The first step to analyze the data that will be gotten from the observation and interview will be first organizing and preparing the data for analysis. This activity involves transcribing interviews, scanning material, tying up field notes, and arranging the data into different types depending on the source information.

The second step is to read all through the data. The first general step is to obtain a general sense of the information and to reflect on its overall meaning. The last step is the researcher began detailed analysis with the coding process. Coding is the process of organizing the material. It involves taking text data or pictures, segmenting sentences. In this case, all the data that have been collected will be fitted to the theory of the experts to support the data finding of this research.

\section{Results}

The data findings were gathered from the observation and interview conducted to the three students of the English Education Study Program and three Economic Education Study Program who are conducting their thesis. Based on the result of observation and interviews conducted with those students, there are some points and aspects of the phenomenon revealed.

\subsection{Respondent 1}

The findings show that the students are suffering from various problems in academic advising. When being asked about their difficulties in conducting the theses research, respondent number 1 elaborates some major points of difficulties encountered. The following data is the details of the difficulties faced by respondent number 1 : 
"....it is the topic. Choosing the topic is always hard. Because we need to think about so many things before we choose a topic. We need to think about whether we can do that or not, has it met the expectation of our lecturer, how we can collect all the literature reviews, and there are so many things that are running and spinning around in my head before I started to choose a topic. So, I think it is difficult to me to choose the topic for I need more than six months just to find the correct or the right topic for my thesis... (Respondents 1, Personal communication, April 10th, 2017)

Moreover, respondent number 1 further explained as follow:

"....honestly, I am afraid when I have to interact with my thesis advisors. It feels like they are too mean when giving suggestions and questions that make me feel under pressure their tone when they speak, indicates that they are mad at me and of course I am feeling so frightened every single time I have to meet up with my thesis advisors... (Respondents 1 , Personal Communication, April 10th, 2017)

\subsection{Respondent 2}

When being asked about the difficulties that they encountered in conducting the thesis, respondent number 2 agreed that one of her biggest problems in writing the thesis or conducting the thesis is because she has insufficient knowledge in writing the thesis. She elaborated further as follow:

"...the problem is that I have the idea or the main topic in my head, but when I start writing, I got stuck on how I should develop my idea or topic into sentences and paragraphs. Sometimes I find difficulties in combining the idea from the experts with my own idea. And you know that, when I get stuck, I tend to be lazy to keep working with my thesis and as the matter of fact, my thesis needs a long long time to be finished ... (Respondents 2, Personal Communication, April 10th, 2017)

"...sometimes I am feeling so scared to start a conversation with my thesis advisors. I even often feel like I am under pressure right before I start meeting my thesis advisors. I also get nervous and it feels very uncomfortable... (Respondents 2, Personal Communication, April 10th, 2017)

"...maybe it is because when we were having the Research on Language subject, we did not really learn about how we need to write our thesis. For example, when we are writing or conducting the thesis we need to concern with the methodology of research. It involves the quantitative and qualitative method and I think the lecturer did not provide us with a detailed understanding about how our methodology of research should be... (Respondents 3, Personal Communication, April 10th, 2017)

Participant number 2 argued that he does not know exactly how to develop the topic into sentences and into a paragraph and finds difficulties in expanding his writing. Thus sometimes, he gets stuck in writing his thesis.

Based on the elaboration above, thus it can be concluded that participant number 2 has a problem in conducting or writing their thesis. In his opinion, the insufficient knowledge in writing a thesis may be caused by the lack of information he got during some subject or course such as Research on Language that he thinks that the lecturer should more detail in giving them an example to do his research.

\subsection{Respondent 3}

"...I do not really understand. I guess that thesis supervisors need to be able to help us as students to face the problems or obstacles that we may find during the thesis conduction. But different things often happen. The thesis advisors give more pressure than I ever expected, thus my expectation of my thesis advisors could not be achieved. It is really frustrating when your thesis advisors become my examiner... (Respondents 3, Personal Communication, April 10th, 2017)

"...I wish my thesis supervisors could give me some more comfortable situation that can make me relax while I am interacting with him. Because I found out it is really frustrating to talk with my thesis advisors.

Based on the interview thus it can be concluded that gender is one of the main factors that could interfere with the relationship between the lecturers and the students themselves.

\subsection{Respondent 4}

"There are several difficulties that I face. First is the difficulty in choosing a topic where finding the source of the problem is a difficulty for me. Second, the lack of knowledge about writing scientific papers, namely the guidebook from the faculty for 
writing theses, is still limited. Third, anxiety in interacting with supervisors. Fourth, limited access in interacting with lecturers due to lack of familiarity with supervisors and lecturers who are soo killer. Fifth, the lack of books and other references (availability in libraries) that are suitable for research. Sixth, the comfort, and pleasure of communicating with the supervisor. Seventh, lack of motivation and suggestions from supervisors for proposals."

\subsection{Respondent 5}

"I have two difficulties. First, the difficulty in choosing a topic. What I feel, ma'am, for choosing a topic, I am doubtful and confused whether if I use this topic according to what I can understand, then for choosing a topic I am confused about where to start and the background and problems. Second, the lack of knowledge about writing scientific papers. As for the rules in writing scientific papers, I still have very little knowledge, Ma'am"

\subsection{Respondent 6}

"I only have three difficulties, ma'am. The first difficulty, I don't read well, ma'am. The second difficulty, I do not understand the theory, ma'am. For the next one, it's my mother personally, especially those of us from outside the area who came to Gorontalo without a vehicle. One of the difficulties for me personally is that I have to go back and forth between campus 4 libraries, regional libraries, campuses, and research sites. This is what I would say is a drag by economic factors. "

\section{Discussion}

Students feel that advising is an electronic approval by the advisor of the student's schedule or they feel that their advisors lack the knowledge and information about their advisees. This can also be explained on the basis that some teaching faculty feel that advising is not part of their specialization and they look down on it. Thus, they would not perform their advising job as they are expected or because their advising session does not match or suit the student's time. Therefore, the student cannot benefit from the set time designated by the advisor. Also, Kutz and Hartnett (2001) reinforce this view by stressing that the problems of academic advising are mainly due to ambiguity of the philosophy, goals, and procedures of academic advising to both students and academic advisors. This is reflected in the students' attitudes towards academic advising and its significance to them.

The previous results put the problem of advising along with its forms and different models on the table for discussion and research by specialists at the university since the university student's need for advising is considered one of his basic needs. This indicates that students are in need of a large-scale advising process, whether on the individual or collective level, in order to help the student overcome his problems, ease them, or adapt themselves to them.

Furthermore, results found that more male students are suffering from academic advising problems than females, taking into consideration the unavailability of male students on campus during the process of academic advising and registration. They do not regularly visit their advisors as females do. In fact, they are working during the university's official and unofficial holidays to be able to pay for their study tuition. It is assumed that females have fewer curriculum activities than males, and they are likely to adhere to the rules, directions, and advisor instructions. Also, most females live inside the university campus which gives them the chance to stay in touch with faculty members and advisors.

Students also indicated that there is clear discrimination between males and females in academic advising as advisors are in favor of females at the expense of males. Thus, this is reflected in the increase of males suffering from problems of academic advising. Besides, significant results were found for gender on student's responsibility, as females' rates higher than males in taking responsibility for their academic success. Results suggested that females take more responsibility for their academic success throughout an academic semester.

The study results also revealed that college and academic years do not indicate any significant difference in academic advising problems. This indicates that the problems of academic advising at the university are not very much influenced by these variables. Despite the diversity of students, they all live in the same social, psychological and academic conditions and suffer from almost similar advising problems. Academic advising problems in university are more likely to be affected by factors other than college and academic year.

Findings revealed a negative correlation between problems of academic advising and students' grade point average. The more the problems of academic advising increase, the lesser the student's academic performance becomes and vice versa. This indicates that academic advising is a good indicator of the level of student performance. The problems of academic advising may overlap and influence the level of motivation and learning strategies, and eventually the academic progress of students at the university. The findings of this study are similar to some findings in the related studies and disagree with others as well. 


\section{Conclusion}

From the interviews with the subjects, it is found that all students or participants believe that the main problems that they face during the thesis conduction are that the limitation of time and the relationship between the lecturers and the students themselves. The result of the data findings and discussion also found out the most common barrier or obstacles/difficulties encountered by the students in conducting their research is that the limited access to the books and important journals which are provided in the library or book stores in Gorontalo. Therefore, it can be concluded that all of the students have been expected to be more comfortable with their thesis advisors and to have more flexibility in communicating with their own thesis advisors.

It is suggested that the entire educational stakeholder in the university and the study programs need to make any improvement to the facilities provided in the library by adding some new books for the students' references. By providing some required facilities, it will not only help the students in acquiring the research material to the students but also it will help the students to be well improved in terms of their English skills and ability and also their acknowledgment to the research development field.

Funding: This research received no external funding.

Conflicts of Interest: The authors declare no conflict of interest.

\section{References}

[1] Bassett, B. (2009). Graduate Education in the United States. McGraw-Hill.

[2] Behling, J. H. (2000). Guidelines for Preparing the Research Proposal (Revised Edition). University Press of America.

[3] Clark, D. C. \& Clark, S. N. (2001). Better Preparation of Educational Leaders. Educational Researcher, 25(9), 18-20.

[4] Creswell, B. (2009). An introduction of Qualitative Research. Trent Focus Group.

[5] Hancock. J. (1998). Metodologi Penelitian Qualitatif [Qualitative Research Methodology]. Remaja Rosdakarya.

[6] Haworth, J. (2003). Assessment in Graduate \& Professional Education. Future Prospects: New Directions for Institutional Research. Jossey Bass.

[7] Kutz, J. \& Hartnett, R.T. (2001). Scholars in the Making. Cambridge MA Balinger.

[8] Madisen, D. (2002). Successful Dissertation and Theses. CA Jossey Bass Press.

[9] Malhotra, I. (2014). Principle of instruction- research-based strategy. Stanford University Press.

[10] Miller, M. (1995). ABD Status and Degree Completion: A Students' Perspective Paper Presented at the American Educational Research Association. Thousand Oaks.

[11] Nerad, M \& Cerny, J. (2005). from Facts to Action: Expanding the Role of the Graduate Division. Council of Graduate School Communicator. Virginia Polytechnic Institute and State University.

[12] Sternberg, D. (2001). How to Complete and Survive a Doctoral Dissertation. New York St Martin's Press.

[13] Sugiyono, S. (2008). Memahami Penelitian Qualitative [Understanding Qualitative Research]. Alfabeta.

[14] Suryana. (2010). Metode Penelitian-Model Praktis Penelitian Kuantitatif dan Kualitatif (Class Handout) Universitas Pendidikan Indonesia [Research Methods - Practical Models of Quantitative and Qualitative Research (Class Handout) Universitas Pendidikan Indonesia]. Universitas Pendidikan Indonesia. 